\title{
How Timber Harvest Affects the Structure and Diversity of a Montane Forest in Southern Mexico
}

\author{
Nayely Martínez-Meléndez ${ }^{1}\left(\mathbb{D}\right.$, Neptalí Ramírez-Marcial ${ }^{1, * \mathbb{D}}$, Pablo Martínez-Zurimendi ${ }^{2}$ (D), \\ Manuel J. Cach-Pérez ${ }^{2,3}$ (D) and José G. García-Franco ${ }^{4}$ \\ 1 Departamento de Conservación de la Biodiversidad, El Colegio de la Frontera Sur (ECOSUR), San Cristóbal \\ de Las Casas, Chiapas 29290, Mexico; namartinez@ecosur.edu.mx \\ 2 Departamento de Agricultura, Sociedad y Ambiente, El Colegio de la Frontera Sur (ECOSUR), Villahermosa, \\ Tabasco 86280, Mexico; pmartinez@ecosur.mx (P.M.-Z.); mcach@ecosur.mx (M.J.C.-P.) \\ 3 Cátedra-CONACyT, Avenida Insurgentes Sur 1582, Mexico City 03940, Mexico \\ 4 Instituto de Ecología A.C., Xalapa, Veracruz 91073, Mexico; jose.garcia.franco@inecol.mx \\ * Correspondence: nramirezm@ecosur.mx
}

Citation: Martínez-Meléndez, N.;

Ramírez-Marcial, N.;

Martínez-Zurimendi, P.; Cach-Pérez, M.J.; García-Franco, J.G. How Timber Harvest Affects the Structure and Diversity of a Montane Forest in Southern Mexico. Forests 2021, 12, 895. https://doi.org/10.3390/f12070895

Academic Editor: W. Keith Moser

Received: 9 June 2021

Accepted: 6 July 2021

Published: 8 July 2021

Publisher's Note: MDPI stays neutral with regard to jurisdictional claims in published maps and institutional affiliations.

Copyright: (c) 2021 by the authors. Licensee MDPI, Basel, Switzerland. This article is an open access article distributed under the terms and conditions of the Creative Commons Attribution (CC BY) license (https:// creativecommons.org/licenses/by/ $4.0 /)$.

\begin{abstract}
Timber extraction directly affects forest structure by opening the canopy, reducing the density and volume of dominant species, and transforming the composition, diversity, and functioning of the forest. We analyze the richness, diversity, and basal area of tree species in a pine-oak montane forest under two stages of the Silvicultural Development Method (thinning and liberation cut treatments) in comparison with remnants of forest considered to be control treatment in the Ocotones forest. Timber extraction began 14 years previously but its effect on the tree structure has not been studied to date in this area. We quantified and measured all the trees with a diameter at breast height $>5 \mathrm{~cm}$ in 120.1 ha circular plots in each treatment. Diversity (Hill numbers) and the importance value index were calculated in each treatment. Observed species richness did not differ between treatments; Pinus oocarpa Schiede ex Schltdl. and Quercus sapotifolia Liebm. were the dominant species regardless of treatment. The principal differences in density and basal area among the treatments were found between the small oaks and small pines. In general, tree density recovered in managed areas because of newly recruited pines and re-sprouting oaks. Although no significant reduction in species richness was detected between treatments, species composition and vegetation structure were modified by the extraction of pine timber and the permanence of many large oaks. Silvicultural treatments appear to create conditions favorable to the maintenance of species richness. The silvicultural interventions in the site meet the objectives of timber production, regeneration, and biodiversity conservation; however, the question of how long the forest can maintain its species diversity and structure after timber extraction remains to be addressed.
\end{abstract}

Keywords: basal area; oaks; pines; Silvicultural Development Method; tree density; tropical montane forest

\section{Introduction}

Tropical forests are considered the most threatened forest ecosystems worldwide due to demographic and economic growth, the mechanization of extraction techniques, and the increase in road and transport infrastructure [1,2]. This has led to a reduction in biodiversity reflected in lower provision of forest ecosystem services [2]. Silvicultural treatment is one of the most important approaches in forest management and for the last 50 years, diverse silvicultural treatments have been implemented worldwide to maximize productive yields in a manner compatible with conservation objectives [3-5]. In the case of Mexico, forest management based on interventions and intensive harvesting through selective logging did not completely guarantee sustainability and failed to consider the component of biological conservation [6]. However, to mitigate ecological modifications to forest stands through selective management, in the early 1970s, the Mexican forestry 
commission proposed some methods of forest planning in pine-oak forests, including the Silvicultural Development Method (SDM [7-9]), which is currently in widespread use in Mexico (www.gob.mx/conafor, accessed 12 November 2020). The SDM is a system of timber harvest by rotation which cover a period of 50-60 years. This method is based on the selection of the parent trees, which begins with a regeneration cutting to promotes the establishment of a new cohort of trees, in which most of the adult trees are removed, but some of the best individuals are left as seed trees. In the second stage, the liberation cut (LC) treatment is applied. LC consists of a release treatment performed in an age class not exceeding the sapling stage to free the favored trees from the influence of less desirable individuals of the same age class, which overtop them or are likely to do so in the future. Finally, the thinning (TH) is a cutting process carried out to reduce the stand density of trees to improve growth and enhance forest health. For more details of SDM stages description, see Section 2.2 in methods.

Since the application of silvicultural methods in mountain forests in Mexico began, attempts have been made to evaluate the biological and environmental consequences of logging. However, little is known about the effects of SDM on the biodiversity but see some effects on tree diversity [10] and on other groups of organisms [11,12]. Studies on the long-term effects of management on the structure and functioning of forests remain scarce and spatially limited [6].

Given the high biological diversity of the humid montane forest in Mexico [13], it is important to recognize that any type of forest management implies changes in species richness and biodiversity and can have possible consequences at a regional scale. For this reason, it is necessary to fully understand the effects of logging on forest composition, structure, and diversity [14].

Protection of original forests is fundamental for biodiversity conservation and mitigation of climate change. In this context, the contribution of managed forests cannot be ignored [15]. There is current interest in ensuring that forest exploitation does not permanently affect ecosystem processes [5]. Understanding the effect of forest management on forest composition and structure would be invaluable to the design and application of good management practices that act to conciliate forest exploitation, biodiversity conservation and the maintenance of ecosystem services [16].

A convenient site to study the effect of SDM on the diversity of woody species in tropical mountain areas is the Ocotones forest. In this site, we determined whether the interventions lead to a forest with an exploitable structure that fulfills the silvicultural objectives, and how the diversity, density and size of the existing trees (that contribute to the conservation of the biodiversity) are modified by this silvicultural intervention. This approach is justified given that the SDM has been criticized for its orientation towards the production of a single or a few species of pines, proposing the elimination of oaks and other broadleaves, considered to be species of little commercial value, which may decrease the forest diversity in the future [17]. In addition, the SDM has faced problems of precise execution in its prescriptions. The low prices of secondary and tertiary wood products limit the possibility of properly applying thinning and making these operations profitable. On the other hand, during the logging of trees in the liberation cut, it causes a lot of damage at ground level and the standing regeneration, particularly on steep slopes. That is why it is common to reduce the cutting intensity [17].

The objective of our study was therefore to evaluate the effect of timber extraction on tree structure and diversity at two stages of the SDM management: thinning II, with the last harvest in 2016, and liberation cut, carried out in 2015. We compare the results with those of remnants of unmanaged forests considered to be conservation areas into the Ocotones forest ordination plan [18]. Particularly this area has not undergone a recent harvest. We also evaluated the variation in density and basal area per size class (small, medium, large) in three groups of tree species (pines, oaks, and other broadleaves). We hypothesize that (1) the lowest richness of tree species will be found in the logged treatments, with respect to the control treatment, (2) if the SDM in the study site involves harvesting of large pine 
trees, the density of small pines will be higher in LC since this is the treatment with the highest volume of timber harvested per year, which contributes high levels of regeneration of seedlings of the species of interest. Moreover, we predicted that the basal area of pines, oaks and other broad leaf species would be lower in the sites with silvicultural treatments respecting to the sites without treatment, due to the harvest of usable individuals with a diameter at breast height $(\mathrm{DBH})>20 \mathrm{~cm}$. On the other hand, we expected the structural attributes of the forest to change depending on size class. We expected that density of small pines would be higher than density of oaks and other broad leaf species in the same size category. Since Quercus spp. is abundant in the study site (since an important number of large trees are left standing during the interventions), we expected that the basal area of oaks would not differ among treatments.

\section{Materials and Methods}

\subsection{Study Area}

The study was carried out in the Ocotones forest, located in the municipality of Cintalapa de Figueroa, Chiapas, southern Mexico $\left(16^{\circ} 47^{\prime} 31.09^{\prime \prime}\right.$ and $16^{\circ} 47^{\prime} 48.97^{\prime \prime} \mathrm{N}, 94^{\circ} 01^{\prime} 29.53^{\prime \prime}$ and $94^{\circ} 02^{\prime} 4.43^{\prime \prime} \mathrm{W}$, Figure 1). Elevation at the site ranges from 800 to $1500 \mathrm{~m}$ asl, and the site forms part of the Chimalapas-Uxpanapa-El Ocote biological corridor, in the physiographic province of Sierras of southern Chiapas [19]. Mean annual precipitation is $1250 \mathrm{~mm}$ and mean annual temperature is $22^{\circ} \mathrm{C}$. The predominant soil types are eutric regosol, chromic cambisol and lithosol with medium texture and a lithic phase [18]. The predominant vegetation type is mixed pine-oak forest $[18,20]$.
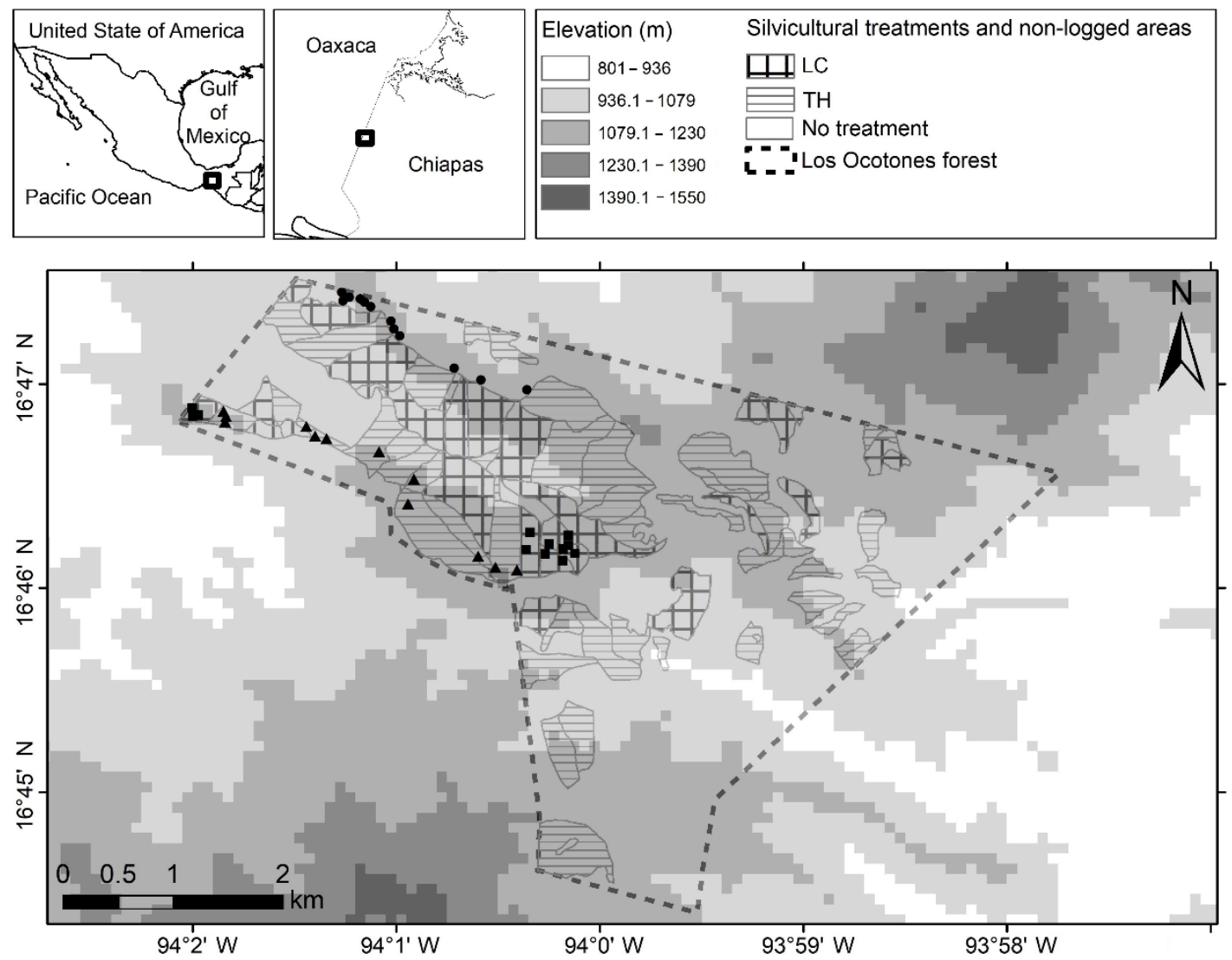

Figure 1. Location of the Ocotones forest in Chiapas, Mexico, and the sampling sites (Triangle: thinning treatment, square: liberation cut treatment, circle: no treatment).

In general, the Ocotones forest has a regime of frequent low intensity forest fires (every two years in 2 or 3 different points into site). They are fires originating in other ejidos or bordering properties that pass through the fire break gaps. Its impact does not replace 
the composition, but it favors the recruitment of pine seedlings. Other disturbances are strong winds every 10-15 years caused by hurricanes, which affect the region in periods of 10-15 years. Additionally, the presence of forest pests (Dendroctonus spp. Bark beetle) has been recorded, but their impact is generally localized, and of low intensity.

\subsection{Silvicultural Development Method (SDM)}

The SDM generally covers a period of 50-60 years (rotation) and allows 3 to 4 intermediate cuts (thinning) during the rotation period, in short cycles of 10 years (which can vary depending on the management program; Figure 2). The cycle begins with a clear-cutting regeneration treatment, which is considered the main harvest phase since almost all the pine trees are used, leaving just 30 to 55 mature trees per hectare. These remaining trees provide the seeds for new recruitment. Ten years later the "liberation cut" treatment is applied, which involves intermediate cuts, i.e., those that are applied throughout the "rotation" period, and the objective is to release the process of natural regeneration. For this, most of the pines parent trees are cut (but around six trees per hectare are left standing) so that the saplings can grow without light competition [8]. Ten years later, a thinning treatment is applied, also involving intermediate cuts, but of greater importance since it is applied to control the stand density. This favors the trees with optimal characteristics for harvesting and eliminates the rest [9]. In certain regions of Mexico, SDM has been modified for adaptation to mixed forest scenarios, comprising species that are shade-tolerant, and with non-uniformly aged broad leaf and coniferous species. The aims of this adjustment is the timely application of silvicultural treatments in order to replace the original forest stands with new stands of optimal density and uniformly aged trees [6].

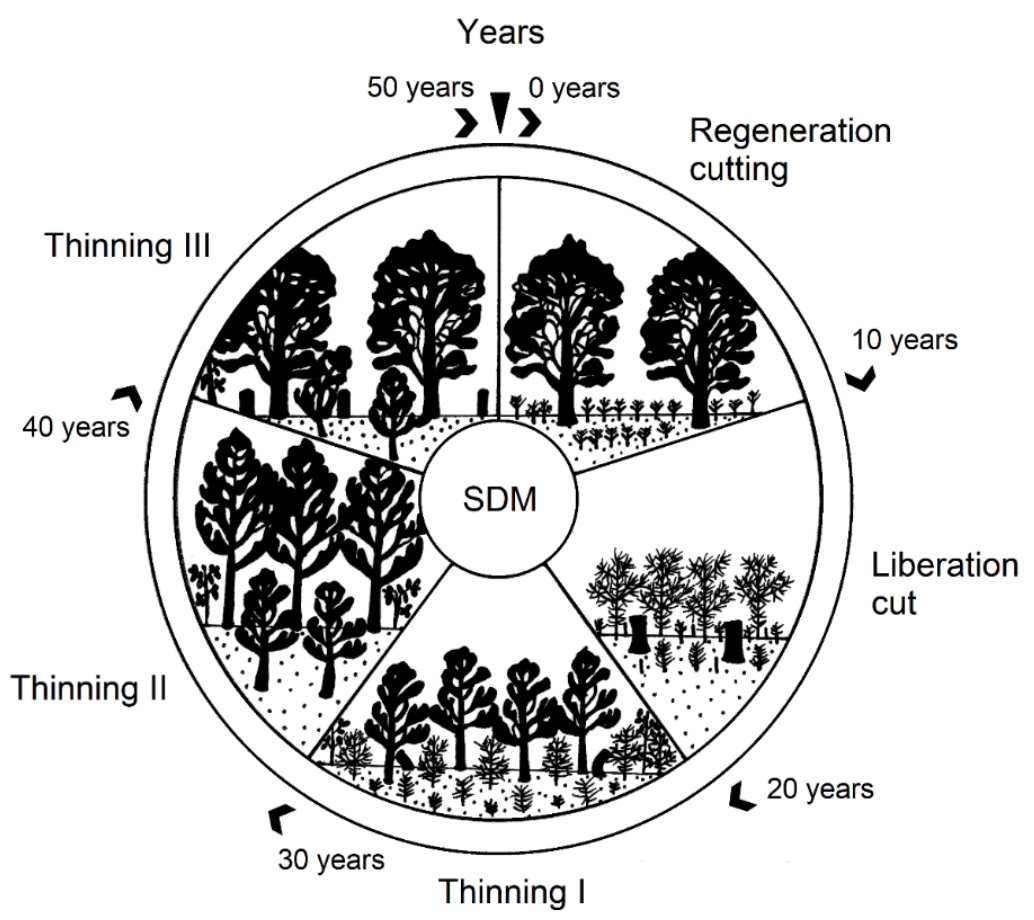

Figure 2. Silvicultural Development Method (SDM) cycle scheme, with a rotation period of 50 years. The age intervals indicate the opportune period for application of each treatment, counting from the beginning of the rotation. Regeneration cutting promotes the establishment of a new cohort of trees, in which most of the adult trees are removed, but some of the best individuals are left as seed trees. Liberation cut (LC) involves intermediate cuts that attempt to release the natural regeneration of the Pinus species. Thinning (TH) involves intermediate cuts in three stages, applied to control the stand density to favor the growth of exploitable individuals. Modified from [21]. 
The Ocotones forest has been subject to forest management under Silvicultural Development Method (SDM) adapted according to local criteria since 1990. The prescriptions include timber harvesting with 45-year rotations and there are five 9-year working plan periods [18]. Therefore, we consider that the interventions in the Ocotones forest are slightly different from the theoretical model indicated in Figure 2. In this forest, the SDM has been implemented during the first working plan period, and the fifth working plan period will be completed in 2048 [18]. Currently, the second working plan period, 2013 to 2021, is being applied and features the harvesting of timber of Pinus oocarpa Schiede ex Schltdl. and Pinus maximinoi H.E. Moore and occasionally Quercus spp. to make charcoal. Cutting intensity is determined according to the treatment prescribed: in TH specifically, $75 \%$ of the pines, $20 \%$ of the oaks and $3 \%$ of the other broad leaf trees. In the liberation cut stage, a residual condition of six adult pines per ha is left, with DBH from 30 to $45 \mathrm{~cm}$. From the other groups of species, such as Quercus and other broad leaf trees, 5\% of each group is left standing, to protect species diversity at local scale.

On the other hand, in the sites chosen for exploitation, $100 \%$ of the trees in the gully areas are left standing. An important proportion of the oaks are left standing ( $R$. Ramos, pers. comm.) and spaced such that they can grow vigorously, since they also form part of the harvest during the interventions [18]. In LC, an average of $105 \mathrm{~m}^{3} \mathrm{ha}^{-1}$ of pines and $30.5 \mathrm{~m}^{3} \mathrm{ha}^{-1}$ of oaks, and $31.9 \mathrm{~m}^{3} \mathrm{ha}^{-1}$ of pines and $8.8 \mathrm{~m}^{3} \mathrm{ha}^{-1}$ of oaks in $\mathrm{TH}$ were harvested (period of 2013 to 2017) [18]. The management plan in the Ocotones forest is regulated by the Secretary of Environment and Natural Resources of Mexico (SEMARNAT, by its Spanish acronym), and exploitation is managed similar to a small private enterprise [18].

\subsection{Selection of Study Sites and Vegetation Sampling}

Thinning (TH), a cutting process carried out in three phases (TH I, TH II, and TH III) to reduce the stand density of trees to improve growth and enhance forest health, and liberation cut (LC), a release treatment performed in an age class not exceeding the sapling stage to free the favored trees from the influence of less desirable individuals of the same age class which overtop them or are likely to do so in the future. We select some stands in LC and TH II stages in discrete sectors of the Ocotones forest (Figure 1). These were chosen since the interest was in evaluating the standing trees rather than the regeneration. We compared these stands with sites with no current forest extraction (NT = no treatment), although it has had some wood extraction (mainly Pinus oocarpa, Pinus maximinoi, and P. chiapensis (Martínez) Andresen) in the past, at least 60 years previously (Figure 3).

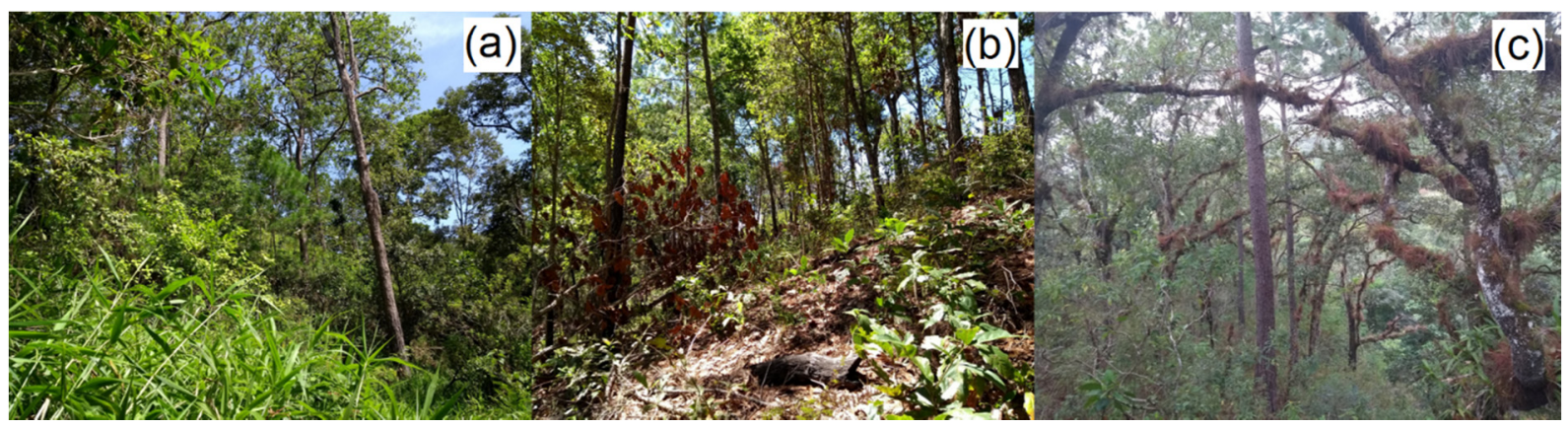

Figure 3. Profile view of the silvicultural treatments in the Ocotones forest, Chiapas, Mexico: (a) Liberation cut, (b) Thinning II, and (c) No treatment.

We selected stands where the same year the interventions had already been carried out for each treatment, which was considered to be replicates. In total, 12 circular plots (each of $0.1 \mathrm{ha}$ ) were established in each treatment and in the sites with no treatment (36 plots in total). The plots were located within an elevational range of 1053-1200 m. a.s.l. and presented slightly inclined to moderately scarped slopes (Figure 3, Table S1). To avoid edge 
effects, the plots were established at a minimum distance of $20 \mathrm{~m}$ apart and at a minimum distance of $30 \mathrm{~m}$ from the edges of other stands. The stands and plots were located using maps generated in the software QGIS [22].

The most recent harvest was in 2016 for TH and in 2015 for LC, during the second working plan period (2013-2021) [18]. These treatments had the first silvicultural intervention in the first working plan period (2004-2012), TH in 2007 and LC in 2006 (R. Ramos pers. comm.; [18]). Prior the start of management plan, this forest was under unregulated timber extraction, which peaked between 1957 and 1977, a period that coincides with large-scale clearing of land for conversion to agriculture and livestock grazing [23]. However, the Ocotones forest maintained a low intensity forestry (due to the steep slopes and good productivity). For this reason, the NT treatment is considered secondary forest rather than old-growth forest.

Fieldwork was conducted from January to December 2018. In each plot, the trees present with diameter at breast height $(\mathrm{DBH}) \geq 5 \mathrm{~cm}$ were sampled. All individuals were counted, identified taxonomically, and their DBH measured with a diametric measuring tape. All the trees were categorized into one of three groups of species: Oaks (Quercus spp.) and Pines (Pinus spp.), which included the dominant species of the canopy and accounted for almost $90 \%$ of the total number of individuals, and Others, which included the broad leaf species other than oaks. Similarly, to categorize the size class distribution within the forest stand, individuals were classified into the following categories: small (DBH 5-10 cm), medium $(\mathrm{DBH} 11-30 \mathrm{~cm})$ and large $(\mathrm{DBH}>30 \mathrm{~cm})$. In addition, we calculated density values (individuals ha $\left.{ }^{-1}\right)$ from the number of trees per plot and basal area $\left(\mathrm{m}^{2} \mathrm{ha}^{-1}\right)$ obtained from the individual DBH values of all the trees of a plot, and the area of that plot [24]. With these data, we obtained the average \pm standard error densities and basal area per size class and species group in each treatment.

To determine the tree structure of the forest in each management conditions $(\mathrm{TH}$, LC, and NT), the tree density was also grouped into five diametric categories to obtain the distribution of frequencies per DBH category $(5-20,21-35,36-50,51-65,>65 \mathrm{~cm})$ of the three groups of species (Pines, Oaks, and Others). The importance value index (IVI) was then calculated for each tree species in each treatment. This was estimated based on the sum of relative values of density (RDe), dominance (RDo, based on basal area) and frequency ( $\mathrm{RFr}$, based on presence within the 12 plots in each treatment), and calculated as follows [24]:

$$
\mathrm{IVI}=(\mathrm{RDe}+\mathrm{RDo}+\mathrm{RFr}) / 3
$$

For adequate control of the taxonomic identity of the species, we obtained botanical vouchers (vegetative or reproductive structures) of the sampled individuals, and an itinerant reference catalogue was prepared. Precise taxonomic identification was possible using specialized keys, comparison with herbarium specimens, and consultation with specialists. A review of updated taxonomic nomenclature was conducted with the help of Flora Mesoamericana (www.tropicos.org/Project/FM, accessed 12 March 2021) and Plants of the World online (http:/ / powo.science.kew.org/, accessed 12 March 2021). In addition to taxonomic identity, we added the successional affinity (early, mid, and late successional) to each species based on the lists of [25-27]. Early successional species typically present a high growth rate, short life span, low wood specific density and high production of small seeds (frequently wind-dispersed). They also form seed banks that remain in the soil for decades after dispersal. Late successional species, however, are characterized by a low rate of growth, high specific wood density, fleshy fruit with large seeds (frequently dispersed by vertebrates) and seeds that germinate soon after dispersion [28]. Between these extremes, the mid-successional species share traits with both early and late successional species [27,29]. Unlike early species, mid-successional species are taller, long life, and propagate vegetatively, but are not as shade-tolerant as late successional species [28]. 


\subsection{Analysis}

\subsubsection{Differences between Silvicultural Treatments}

Generalized linear models (GLM) were used to determine whether the structural variables differed significantly among silvicultural treatments [30]. We used the negative binomial distribution for density (counts) and gamma for the basal area (continuous data). The density and basal area values of trees of each size class (small, medium, and large) and group of species (Oaks, Pines and Others) of the treatments were compared. Nine models were constructed for each response variable by combining the three size classes and the three species groups. In all the models, distribution of residuals and overdispersion were verified. When the model was significant, post hoc contrasts were performed with the Tukey test. The significance value at which to determine differences was $p<0.05$. The models were generated with the glm function and the MASS library [31]. We used a chi squared $\left(\chi^{2}\right)$ test to compare the distribution of the diametric (DBH) classes of each group of species among treatments. For the post hoc tests, the multcomp library [32] was used. All analyses were performed using R software, version 3.6.0 [33].

\subsubsection{Species Diversity}

To evaluate tree diversity, we used the true diversity approach [34]. This approach considers species abundance values to obtain three diversity parameters that are represented by Hill numbers: ${ }^{0} D$ : effective number of species (observed richness), ${ }^{1} D$ : common species (equivalent to the exponential of the Shannon index), ${ }^{2} D$ : dominant species (equivalent to the inverse of the Simpson index). True diversity values were obtained with the rarefaction (interpolation) and extrapolation (prediction) methods. We used rarefaction and extrapolation because the number of individuals can vary systematically with each treatment, which could lead to bias in the species diversity estimates conducted in plots with more individuals. This is a method of standardization that generates species accumulation curves, and confidence intervals at $95 \%$ are calculated with the bootstrapping method, so species diversity can be quantified and compared visually in multiple ensembles [35]. The analysis was performed with species abundance data per plot, within each treatment. For the analysis, we used the iNEXT library [35] in R software, version 3.6.0 [33].

\section{Results}

\subsection{Composition and Species Diversity}

We recorded a total of 3488 trees with $\mathrm{DBH}>5 \mathrm{~cm}$ in the 36 plots of all the treatments: 923 in TH, 1284 in LC, and 1283 in NT. These trees represented 47 woody species belonging to 38 genera and 32 families; Fagaceae and Fabaceae presented the highest species richness (Table S2). No significant differences were found in species richness $\left({ }^{0} D\right)$ among treatments $\left({ }^{0} D_{\mathrm{TH}}=31,{ }^{0} D_{\mathrm{NT}}=30,{ }^{0} D_{\mathrm{CL}}=29 ; p=0.368 ;\right.$ Figure 4$)$.

Of the 47 species, we recorded 14 early, 26 mid-, and seven late successional species. Regarding the total number of species recorded in each treatment, the highest number of early successional species was found in $\mathrm{TH}(10)$, while that of mid-successional species was found in NT (20), and that of the late successional species in LC (4) (Table 1, see Table S2). In all the treatments, there were more mid-successional species than those of the other successional categories (20 in NT, 19 in LC, and 18 in TH; Table 1).

The Oak group included Quercus acutifolia Née, Q. calophylla Schltdl. and Cham., Q. elliptica Née, Q. glaucescens Bonpl., Q. peduncularis Née, and Q. sapotifolia Liebm. The Pine group comprised Pinus maximinoi H.E. Moore and P. oocarpa Schiede ex Schltdl. The group of Others comprised 40 species from 32 different families (see Table S2). 

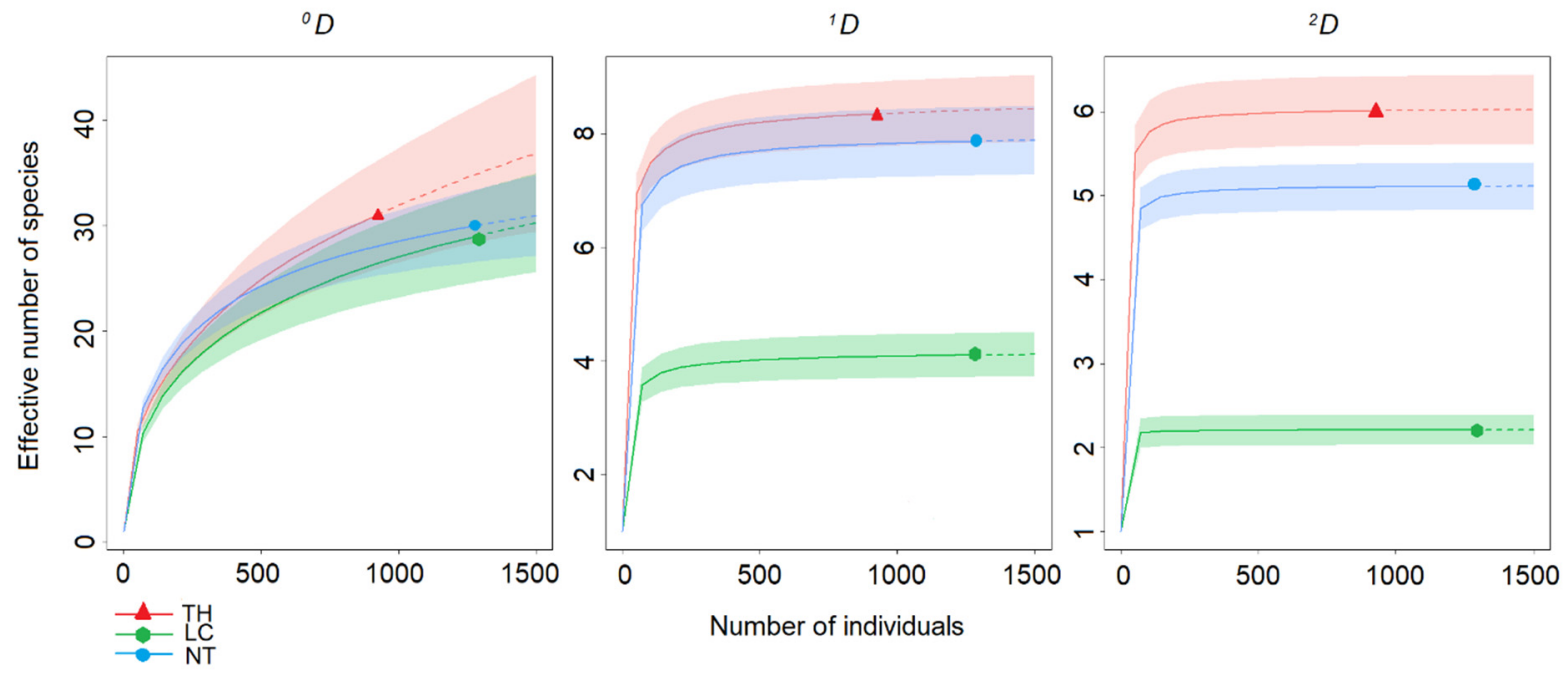

Figure 4. Accumulation curves of tree species in two forest management treatments compared to a site with no treatment in the Ocotones forest, Chiapas, Mexico. Continuous lines indicate interpolation (rarefaction), while broken lines denote extrapolation. Diversity is represented by Hill numbers: ${ }^{0} D$, observed richness; ${ }^{1} D$, common species; ${ }^{2} D$, dominant species. Color bands correspond to the confidence interval at 95\%. TH $=$ Thinning II, LC = Liberation cut, and NT = No treatment.

Table 1. Accumulated number and percentage of families, genera, and species recorded in different silvicultural treatments in the Ocotones forest, Chiapas, Mexico. Numbers of species are separated according to successional category.

\begin{tabular}{|c|c|c|c|c|c|c|c|}
\hline \multirow{2}{*}{ Parameter } & & \multicolumn{6}{|c|}{ SDM Treatments } \\
\hline & Thinning II & $\%$ & Liberation Cut & $\%$ & No Treatment & $\%$ & Total Number \\
\hline Species & 31 & 66 & 29 & 62 & 30 & 64 & 47 \\
\hline Genera & 24 & 63 & 23 & 61 & 24 & 63 & 38 \\
\hline Families & 20 & 63 & 20 & 63 & 21 & 66 & 32 \\
\hline \multicolumn{8}{|c|}{ Successional category } \\
\hline Early & 10 & 32 & 6 & 21 & 8 & 27 & 14 \\
\hline Mid & 18 & 58 & 19 & 65 & 20 & 66 & 26 \\
\hline Late & 3 & 10 & 4 & 14 & 2 & 7 & 7 \\
\hline Total & 31 & 100 & 29 & 100 & 30 & 100 & 47 \\
\hline
\end{tabular}

Observed species richness $\left({ }^{0} D\right)$ did not differ between the treatments $(p>0.05)$ (Figure 4). In contrast, the most common species $\left({ }^{1} D\right)$ were significantly lower in LC (4 species) than in TH (6) and NT (8). The number of dominant species $\left({ }^{2} D\right)$ differed significantly among the three treatments; LC was the least diverse treatment, with two dominant species, while TH had six dominant species. The accumulation curve of observed species $\left({ }^{0} D\right)$ indicated that the number of species relative to the number of individuals was higher in TH than in LC and NT (Figure 4).

\subsection{Community Structure}

Tree density did not differ among treatments ( $p=0.25$; Table 2). By species group, the density of the Oak group was statistically different among treatments $(p<0.001)$; the highest density was registered in the NT plots and the lowest in the LC treatment. The highest density of the Pine group also differed among treatments $(p<0.001)$; the highest was in LC and the lowest in NT. The average densities of the Others group did not differ among treatments $(p=0.48$; Table 2$)$. 
Table 2. Tree density (No. ind. $\mathrm{ha}^{-1}$ ) and basal area of trees $(\mathrm{DBH}>5 \mathrm{~cm}$ ) in three silvicultural treatments in southeastern Mexico. Average values \pm standard errors are shown for each variable, per species group and size class. Different letters indicate significant differences in each row (GLM and Tukey post hoc test $p<0.05$ ). The highest values per species group and size class in each treatment are shown in bold font.

\begin{tabular}{|c|c|c|c|}
\hline Variables & Thinning & Liberation Cut & No Treatment \\
\hline Density (individuals $\mathrm{ha}^{-1}$ ) & $766.66 \pm 40.25$ & $1070 \pm 71.12$ & $1069 \pm 40.66$ \\
\hline \multicolumn{4}{|l|}{ Species groups } \\
\hline Oaks & $446 \pm 26^{b}$ & $266 \pm 20^{c}$ & $723 \pm 53^{a}$ \\
\hline Pines & $254 \pm 24^{b}$ & $703 \pm 78.78^{a}$ & $213 \pm 21^{b}$ \\
\hline Others & $67 \pm 7$ & $101 \pm 10$ & $133 \pm 14$ \\
\hline \multicolumn{4}{|l|}{ Size classes } \\
\hline Small & $426 \pm 59$ & $698 \pm 131$ & $656 \pm 82$ \\
\hline Medium & $279 \pm 40$ & $289 \pm 49$ & $315 \pm 32$ \\
\hline Large & $63 \pm 7$ & $83 \pm 9$ & $98 \pm 8$ \\
\hline Basal area $\left(\mathrm{m}^{2} \mathrm{ha}^{-1}\right)$ & $21.1 \pm 6.1$ & $23.8 \pm 6.3$ & $26.9 \pm 4.5$ \\
\hline \multicolumn{4}{|l|}{ Species groups } \\
\hline Oaks & $15 \pm 0.6$ & $14.6 \pm 0.8$ & $18.7 \pm 0.6$ \\
\hline Pines & $5.7 \pm 0.5$ & $8.7 \pm 1$ & $7.5 \pm 0.5$ \\
\hline Others & $0.4 \pm 0.5$ & $0.6 \pm 0.6$ & $0.7 \pm 0.9$ \\
\hline \multicolumn{4}{|l|}{ Size classes } \\
\hline Small & $1.9 \pm 0.2$ & $3 \pm 0.6$ & $2.9 \pm 0.3$ \\
\hline Medium & $6.5 \pm 0.8$ & $5.6 \pm 0.8$ & $7 \pm 0.8$ \\
\hline Large & $12.8 \pm 1.7$ & $15.2 \pm 1.5$ & $17.2 \pm 1.4$ \\
\hline
\end{tabular}

In terms of size classes, the density of the group of small trees was higher in LC, while the densities of medium and large trees were higher in NT; i.e., a decrease in tree density was observed with increasing size class (Table 2). However, there were no significant differences in the density of size classes among the treatments $(p>0.95)$.

In Small Oaks, mean density ( \pm standard error) per size class and species group differed significantly among treatments $(p<0.001)$ : density values in Small Oaks were higher in NT (418 \pm 98 individuals ha $\left.{ }^{-1}\right)$ and lower in LC (treatment with greater canopy opening; $123 \pm 25$ individuals ha ${ }^{-1}$; Figure 5). Density values in the Medium Oaks also differed among treatments $(p=0.002)$, with the highest density values recorded in NT (233 \pm 35 individuals ha $\left.{ }^{-1}\right)$ and the lowest in LC $\left(78 \pm 21\right.$ individuals ha $\left.{ }^{-1}\right)$. In contrast, the density values in Large Oaks did not differ significantly among treatments $(p=0.10$; Figure 5).

The highest mean density of Small Pines was in LC, while the lowest were found in NT (464 \pm 128 ind. ha ${ }^{-1}, 91 \pm 25$ ind. ha ${ }^{-1}$, respectively; $\left.p<0.001\right)$. There were no differences in the density values of Medium Pines $(p=0.15)$ and Large Pines $(p=0.47)$ among treatments, nor were there significant differences in the density values of Small Others $(p=0.02)$, Medium Others $(p=0.5)$ or Large Others ( $p=0.38$ ) among treatments (Figure 5).

In general, the average values of basal area did not differ among treatments $(p=0.46)$ (Table 2). Likewise, per size class and per species group, there were no differences among treatments $(p>0.05)$. In contrast, we observed an increase in the values of basal area with increased size class (Table 2, Figure 6). 


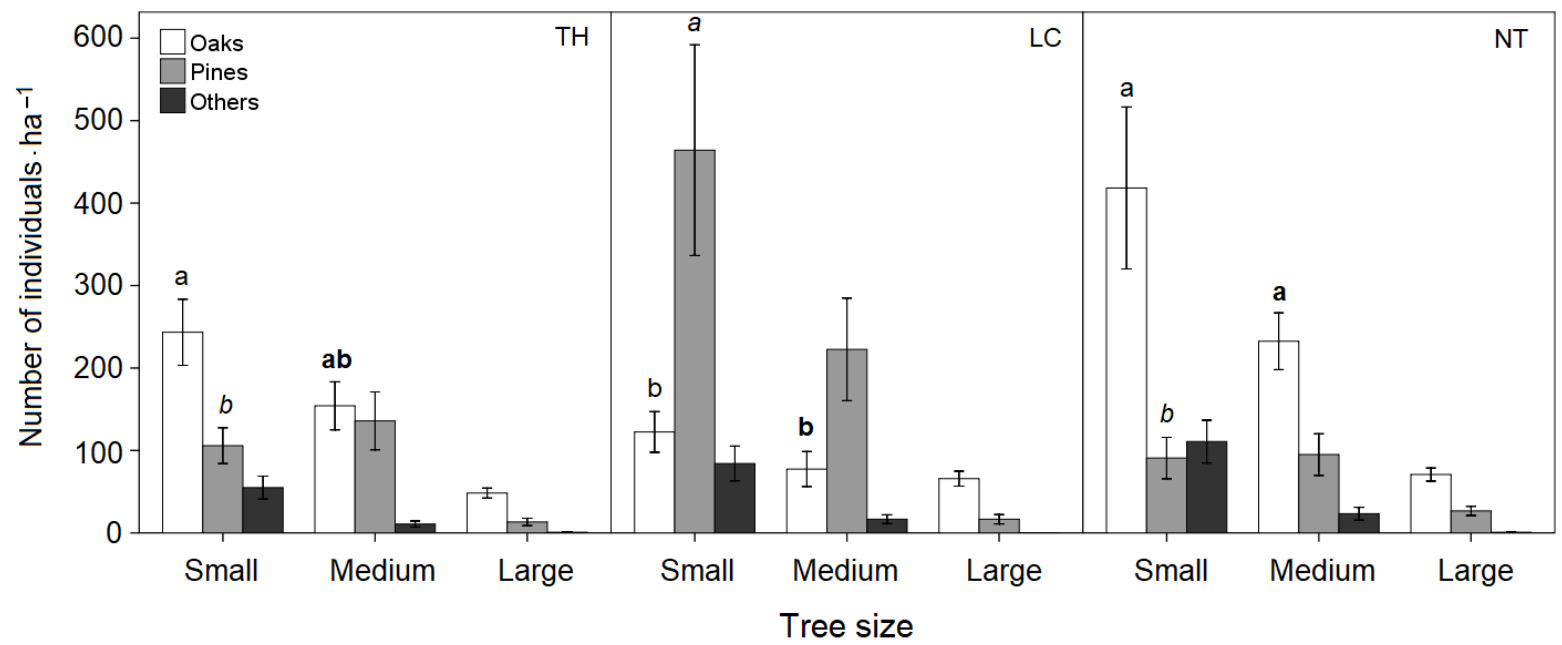

Figure 5. Comparison of density (mean \pm standard error) of trees of each species group (Oaks, Pines and Others) for the same size class (small DBH 5-10 cm, medium DBH 11-30 cm and large DBH > $30 \mathrm{~cm}$ ) in silvicultural treatments in the Ocotones forest, Chiapas. TH = Thinning II, LC = Liberation cut, and NT = No treatment. Densities that differed significantly $(p<0.05)$ are shown with different letters above bars. Normal font for Small Oaks comparisons, italics for Small Pines and bold for Medium Oaks.

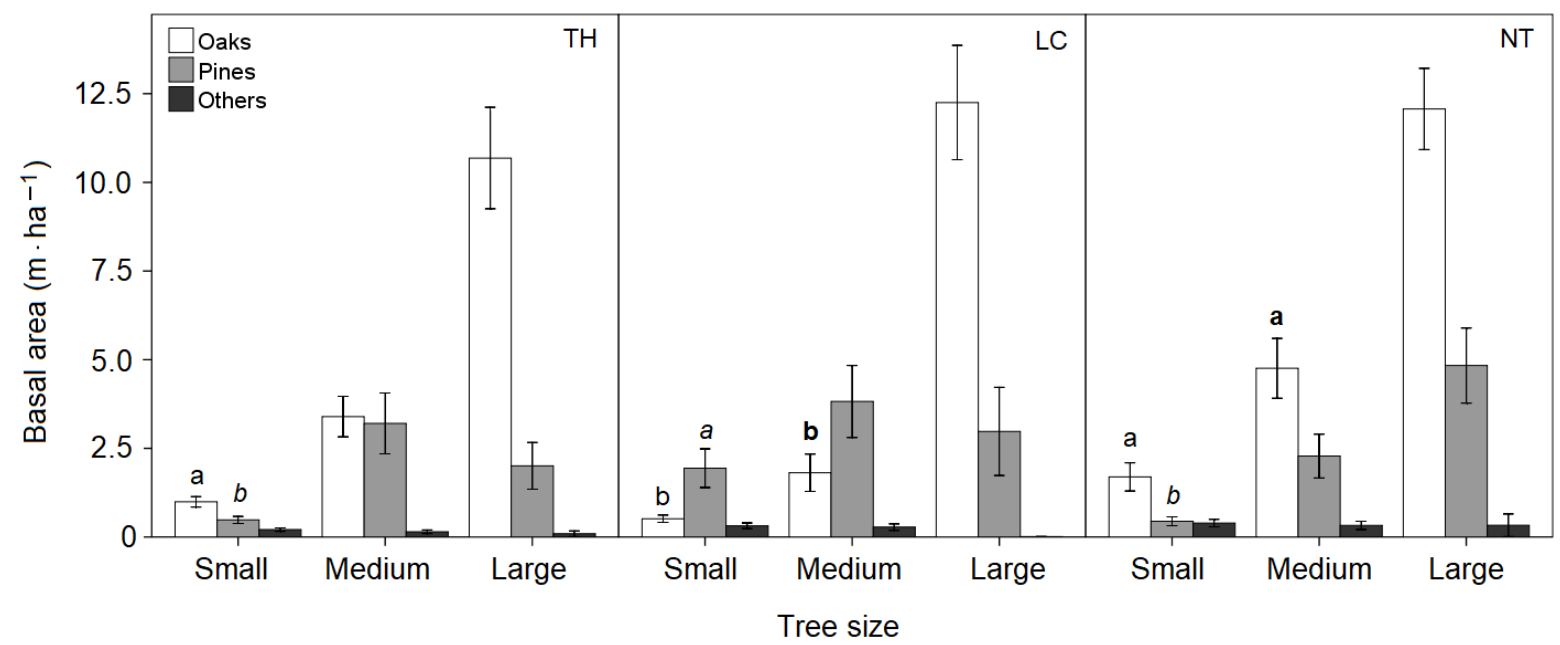

Figure 6. Comparison of the basal area values (mean \pm standard error) of trees from each species group (Oaks, Pines and Others) for the same size class (small DBH 5-10 cm, medium DBH 11-30 cm and large DBH > $30 \mathrm{~cm}$ ) in silvicultural treatments in the Ocotones forest, Chiapas. TH = Thinning II, LC $=$ Liberation cut, and NT = No treatment. Densities that differed significantly $(p<0.05)$ are shown with different letters above bars. Normal font for Small Oaks comparisons, italics for Small Pines, and bold for Medium Oaks.

Per size class-species group, the averages of basal area of Small Oaks differed among treatments $(p<0.001)$. The highest basal area values of Small Oaks were recorded in NT $\left(1.7 \pm 0.4 \mathrm{~m}^{2} \cdot \mathrm{ha}^{-1}\right)$ and the lowest in LC $\left(0.5 \pm 0.1 \mathrm{~m}^{2} \cdot \mathrm{ha}^{-1}\right)$. The basal area of Medium Oaks differed among treatments $(p=0.01)$ : the highest values were in NT and the lowest in LC. The basal area values of Large Oaks did not differ among treatments $(p=0.52)$.

Mean basal area of Small Pines differed among treatments $(p<0.001)$ : the basal area of Small Pines was highest in LC $\left(1.9 \pm 0.5 \mathrm{~m}^{2} \cdot \mathrm{ha}^{-1}\right)$ and lowest in NT $\left(0.4 \pm 0.1 \mathrm{~m}^{2} \cdot \mathrm{ha}^{-1}\right)$. Basal area values of Medium Pines $(p=0.43)$ and Large Pines $(p=0.15)$ did not differ among treatments (Figure 6).

We found a descending distribution of the frequencies of individuals per DBH category in each of the treatments (Figure 7). There were significant differences in the dis- 
tribution of DBH values in the Oaks species group $\left(\chi^{2}=54.9\right.$, d.f. $\left.=8, p<0.05\right)$ and Pines group $\left(\chi^{2}=110.5\right.$, d.f. $\left.=8, p<0.05\right)$ when compared among treatments; but not in Others group $\left(\chi^{2}=5.3\right.$, d.f. $\left.=8, p>0.05\right)$. The site with no treatment had more small individuals (DBH 5-20 cm) of Others than the sites with management. There were more medium trees (DBH 21-35 and 36-50 cm) of Others in the site with LC management. Large individuals $(>50 \mathrm{~cm}$ DAP) of Others were absent in all three sites (Figure 7).

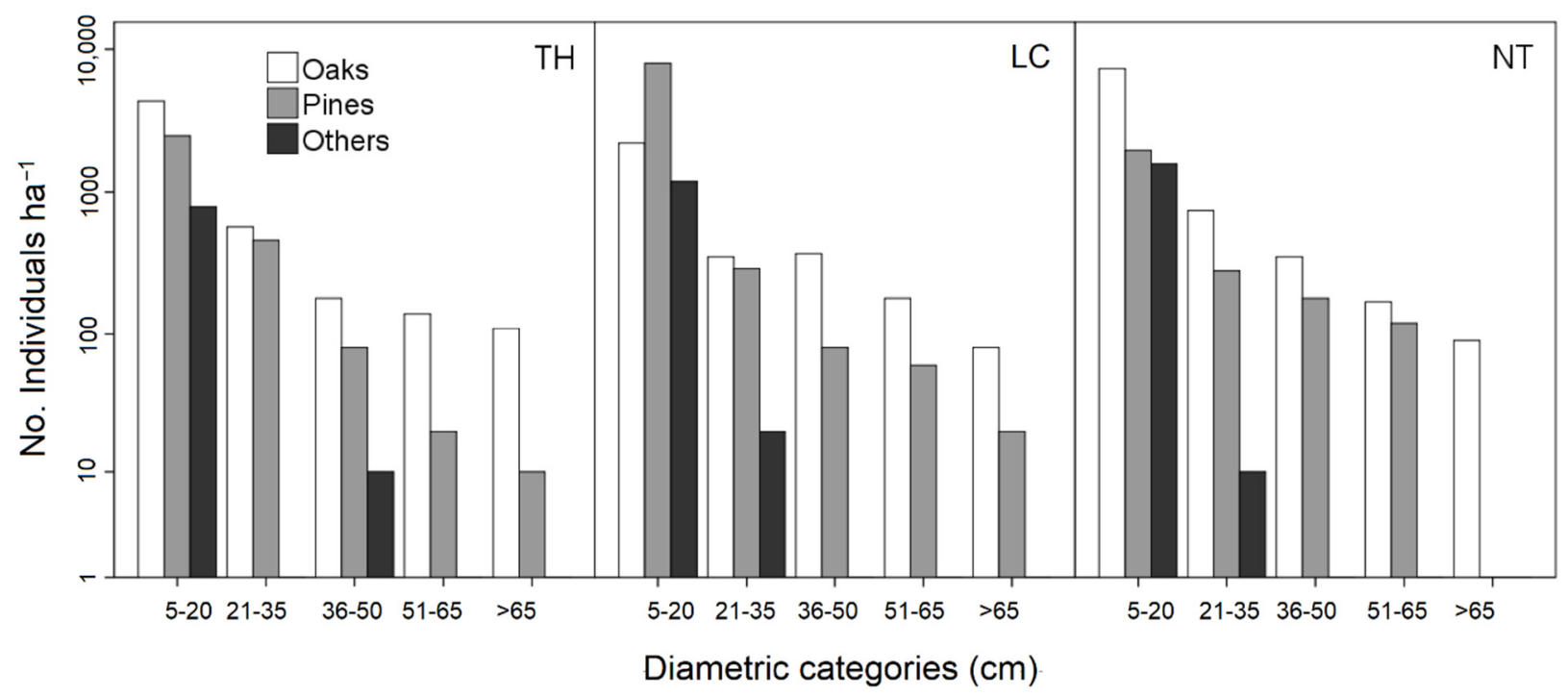

Figure 7. Number of individual trees per diametric category recorded in the silvicultural treatments in the Ocotones forest, Chiapas. TH = Thinning II, LC = Liberation cut, compared to a site with no silvicultural treatment (NT) in the Ocotones forest, Mexico.

In terms of the importance value index (IVI), although Quercus and Pinus together only accounted for $17 \%$ of the species recorded, the two genera represented $87.5 \%$ of the IVI in the entire forest community (Table 3). The species with highest dominance (IVI) were Pinus oocarpa and Quercus sapotifolia; these species had total IVI values above $60 \%$ (65.5\% and $65.3 \%$, respectively), followed by Q. glaucescens and Q. peduncularis with just over $40 \%$ in all treatments (Table 3). In TH, the dominant species was Q. sapotifolia (26\%), in LC this was P. oocarpa (35.2\%) followed by Q. glaucescens ( $22.3 \%)$, while in the sites with no treatment, Q. sapotifolia was dominant with $26.1 \%$ (Table 3 ).

In general, dominance of the Oaks group was higher than the rest of the species groups, with more than $50 \%$ of the IVI in all treatments. It was found to be highest in TH $(66.03 \%)$. The highest value of the Pines group occurred in LC (35.2\%), and of the Others group in NT (15.24\%; Table 3). The complete IVI values calculated by species can be consulted in Table S3. 
Table 3. Importance value index (IVI) for the dominant species recorded under silvicultural treatments in the Ocotones forest, Chiapas, Mexico. Other species with an IVI of less than $1 \%$ can be found in Table S3.

\begin{tabular}{|c|c|c|c|c|c|c|}
\hline Treatment & Oaks Group & $\begin{array}{c}\text { IVI } \\
\%\end{array}$ & Pines Group & $\begin{array}{c}\text { IVI } \\
\%\end{array}$ & Others Group & $\begin{array}{c}\text { IVI } \\
\%\end{array}$ \\
\hline \multirow[t]{6}{*}{ Thinning II } & Quercus acutifolia & 0.09 & Pinus maximinoi & 11.09 & Clethra mexicana & 2.02 \\
\hline & Q. calophylla & 3.47 & P. oocarpa & 12.64 & Saurauia aspera & 1.19 \\
\hline & Q. elliptica & 5.50 & & & Vaccinium leucanthum & 2.59 \\
\hline & Q. glaucescens & 17.88 & & & $\Sigma$ IVI from 20 species $<1$ & 4.43 \\
\hline & Q. peduncularis & 13.03 & & & & \\
\hline & Q. sapotifolia & 26.07 & & & & \\
\hline Total & & 66.03 & & 23.74 & & 10.23 \\
\hline \multirow[t]{6}{*}{ Liberation cut } & Quercus acutifolia & 0.15 & Pinus oocarpa & 35.25 & Clethra mexicana & 1.91 \\
\hline & Q. calophylla & 1.98 & & & Rhus striata & 1.67 \\
\hline & Q. elliptica & 7.02 & & & Saurauia aspera & 2.20 \\
\hline & Q. glaucescens & 22.31 & & & Vaccinium leucanthum & 1.47 \\
\hline & Q. peduncularis & 5.32 & & & $\Sigma$ IVI from 18 species $<1$ & 4.61 \\
\hline & Q. sapotifolia & 16.10 & & & & \\
\hline Total & & 52.88 & & 35.25 & & 11.86 \\
\hline \multirow{6}{*}{ No treatment } & Quercus calophylla & 10.55 & Pinus maximinoi & 2.74 & Clethra mexicana & 1.16 \\
\hline & Q. elliptica & 4.17 & P. oocarpa & 17.60 & Heliocarpus americanus & 1.02 \\
\hline & Q. glaucescens & 3.44 & & & Rhus striata & 1.01 \\
\hline & Q.peduncularis & 23.22 & & & Ternstroemia tepezapote & 4.90 \\
\hline & Q. sapotifolia & 23.05 & & & Vaccinium leucanthum & 2.67 \\
\hline & & & & & $\Sigma$ IVI from 18 species $<1$ & 4.48 \\
\hline Total & & 64.42 & & 20.34 & & 15.24 \\
\hline
\end{tabular}

\section{Discussion}

\subsection{Composition and Species Diversity}

The objective of silvicultural actions is to intervene in and modify the original forest structure and composition. Pine-oak forestry implies the gradual elimination of reproductive individuals and the reduction in number of individuals of broad leaf species [36], especially when the silvicultural treatments are intensive [37,38]. Disturbance and modification of forests by timber extraction are associated with lower abundance of late-succession species and higher abundance of pioneer species, such as pines [14]. Moreover, there is lower tree diversity at the local scale [39].

The largest proportion of pioneer species $(32.3 \%)$ was observed in $\mathrm{TH}$, where the tree density is mainly reduced to improve the growth of trees of commercial interest. The pioneers and their success in clearing is due to their rapid growth, their ability to recruit propagules from the soil seed banks, or through the arrival of seeds following a disturbance [40], as occurs after the application of thinning to the vegetation. In all the treatments, most of the species were from the mid-successional stages. Between $25 \%$ and $30 \%$ of the most common Quercus species in Chiapas are late successional [41], but the oaks recorded in our study have previously been reported as mid-successional [26,27]. This is consistent with the dynamic in the conservative application of the SDM, and it is possible that the irregular historical management in the forest acted to modify the composition of the sites that are currently not managed and have been designated as conservation areas in the current management plan.

Late successional species were better represented in LC. It was expected that these species would be more abundant in sites without treatment (NT), simply because they had fewer disturbances in the past $[36,40]$. However, we recorded only two late successional species in the NT plots: Persea liebmannii Mez and Topobea laevigata (D. Don) Naudin.

Although natural regeneration is a process that is arrested under these silvicultural treatments that prevent timber species from having competition, we can infer that some adjustments of the management prescriptions have allowed a few individuals of some midand late successional species to remain following the timber harvest (nine species in all 
treatments). Although the management prescribes that part of the non-target vegetation should be eliminated during the treatments ( $\mathrm{TH}$ and LC), the trees left standing ( $25 \%$ of pine and more than $80 \%$ of the oaks and other broad leaf trees in $\mathrm{TH}$, and 6 adult pine trees and $5 \%$ of the oaks other broad leaf trees in LC) as a consequence of management applied while strictly following local criteria can contribute to the process of secondary succession and regeneration of late-succession species. For example, in our study, TH (the treatment with intermediate cutting intensity) maintains the same number of common species $\left({ }^{1} D\right)$ as NT (the site with no treatment) although, in TH treatment, there should be fewer common species. Nevertheless, these remnant trees can function as seed sources to facilitate forest recovery [42] in managed sites.

Contrary to our expectations that notable differences would be found in species richness among treatments, the results indicate that the Silvicultural Development Method (SDM) has not affected tree species richness in the second cycle of cutting still in force in this site, which had previously been intervened in the first cutting cycle, beginning in 2004 . In contrast, in other pine-oak forests with silvicultural management such as SDM, it was found that tree species richness declines due to harvesting or the treatments implied by the management $[43,44]$. Some authors suggest and have demonstrated that besides species richness, other forest attributes such as structure, composition and ecological function are negatively influenced by management [14,38,45].

Species richness is not the only forest attribute that is modified by management; there are also changes in diversity, abundance, density, and species importance value, among others [45]. Although our results indicate that species richness has been unaltered by the forest management, structural variables were modified by a direct effect on density. For example, the number of common species $\left({ }^{1} D\right)$ and of dominant species $\left({ }^{2} D\right)$ was significantly lower in LC. This may be because LC is the treatment that involves more timber extraction and thus a reduction in stand density. According to some authors [37,46], unlike forests that are not cut, a forest with selective logging can take more than 40 years to recover its species richness, especially when the cutting intensity is high [38].

Our results suggest that silvicultural management has not drastically affected species richness in managed sites, in the 2 years for $\mathrm{TH}$, and 3 years for LC, following the last silvicultural intervention. This should motivate the continuity of more detailed longer-term studies on variation in plant richness and diversity in this forest. Theoretically, silvicultural treatments are technically precise where the objective of SDM is to apply silvicultural treatments that proceed at a constant and rapid rate in order to replace original forest stands with new stands of optimal density and uniform age [6]. In practice, plant heterogeneity is high in the forests where SDM has been applied, including the stands in our study. This is a consequence of the interventions that were designed to achieve the objectives of the management applied in the Ocotones forest. We believe that although the current physiognomy and composition of this forest is a consequence of recent management, the irregular and scant historical knowledge of the management that began 60 years ago in the region should also be considered [23]. Our results of forest management activities show to be highly variable; therefore, stands with different logging histories create current heterogeneous areas in their structure and forest composition [46]. On the other hand, we consider that the effective implementation of silvicultural treatments is conditioned by the heterogeneous local characteristics of the terrain, where extraction and hauling is complicated due to steep slopes. This causes a variation in the agglomeration of the remaining forest mass after the interventions in each treatment, which in the Ocotones is causing the impact to be less than in other sites with forest management.

\subsection{Community Structure}

In the managed sites (TH and LC), the Pines group had higher densities than the Oaks and Other groups. Pinus oocarpa obtained the highest density values in all groups and treatments. These results coincide with our hypothesis that the density values of pines would be higher in managed sites since this species is the target of the SDM. The 
fact that pines are successful elements in open habitats, even in unfertile sites [47], favors recruitment and growth in managed sites. In contrast, oaks and the other broad leaf species were more abundant in unmanaged sites (NT). This is because Quercus species are generally dominant elements along the forest succession and form a principal part of the tree structure of temperate forests [25,36,48].

Rutten et al. [49] and Ding et al. [14] report that forests managed by selection and thinning had higher tree density than unmanaged forests after 30 to 40 years, particularly because there was a higher relative density of trees with $\mathrm{DBH}<50 \mathrm{~cm}$, principally late successional species. In our study, managed sites (LC and TH) also had tree densities 2.8 times higher than unmanaged sites but comprising species of commercial interest. Density was highest in the Small class in all the treatments. In contrast, the lowest density was for large trees of the three species groups since this class includes a few Quercus and Pinus individuals that were left standing after application of SDM. Although these do not contribute with high densities, they can serve other purposes: e.g., adult pines are sources of seed for new recruitment that contributes to forming a new forest mass, and large trees are used to conserve epiphytes [18]. In the case of Quercus, the high density of individuals in the Small class functions, for example, as a driver of the structure and composition of more diverse communities, and they can reach high density values [50]. In our study, Quercus was the genus with the highest number of species. There is a significant increase in Quercus trees of large diameter with high basal area, caused by the cleaning and thinning of the plant cover undertaken during the silvicultural treatments [43]. In other montane forests with forest management, some of the structural variables, such as basal area, have been found not to differ significantly between managed and unmanaged areas [49].

Much of the SDM rationality anticipates the increased regeneration of Pinus oocarpa, a species with high post-harvest regeneration densities [47]. Indeed, it has been seen that the density of small pine trees can be twice that of small trees of some species of Fagaceae [50]. Our results highlight the importance of Quercus and Pinus as dominant elements following timber extraction. This is consistent with the results of recent studies of Mexican pine-oak forest regeneration patterns [50]. Unlike our observations, however, other authors have not detected differences in tree density between managed and unmanaged sites, although they have observed a higher relative abundance of small trees and lower abundance of commercial tree species [49]. Although differences in the density and basal area of trees between silvicultural treatments may depend largely on cutting intensity $[14,49]$ in the studied forest, it appears that the density of Oaks and Pines shows a similar response to SDM management.

Moreover, our results concerning dominance greatly support the importance of the Oaks group within the general species composition, since it had the highest IVI in all the treatments. Generally, Quercus species is common dominant element of the montane forests in the Sierra Madre of Chiapas region and can dominate the canopy tree stratum [20,27], as the same has been reported by González-Tagle et al. [48] for the Sierra Madre Oriental of Mexico. Quercus species together can make up more than $60 \%$ of the IVI due to the large sizes they can reach [48].

The highest IVI among the treatments of Oaks group was in TH, being Q. sapotifolia the species with the highest IVI. Nevertheless, it is evident that Quercus is not only a genus of importance in the composition of sites with and without management, but also is of high structural importance. Future composition of the forest will depend largely on the permanence of the oaks now present in the sites under forest management since Quercus species promote favorable microenvironmental conditions for the recruitment of other species that are shade-tolerant [29].

Although large Quercus trees remain, there is no possibility that regeneration of the oaks will continue in the study area. Our results show that the density of Small and Medium individuals is up to two or three times lower in managed (TH and LC) than in unmanaged (NT) sites. Oak trees that obstruct extraction operations are generally cut, but occasionally oaks with diameters between $20-40 \mathrm{~cm}$ in diameter are removed. Although 
many young oaks can be damaged, they do not die and eventually recover. In the forest management system, clean cutting in both silvicultural treatments (TH and LC) involves the elimination of any young individuals of species that are not Pinus spp.

It is also important to recognize the presence of Q. sapotifolia as the dominant species in TH and NT. Trujillo-Miranda et al. [51] found that in mixed forests, even though native species have been planted, $Q$. sapotifolia has dominated in the categories of seedlings and saplings among the species that have regenerated naturally, which contrasts with forests with pine plantations. This suggests that $Q$. sapotifolia and other oak species may be important elements to consider in forest restoration and conservation strategies.

In our study, dominance (IVI) of Quercus was higher than that of Pinus in all the treatments. The Quercus IVI was more than $50 \%$, while that of Pinus was $20 \%$ to $35 \%$, and that of the other species was not more than $16 \%$; i.e., even though the Pinus species are those that should be favored by opening the canopy in the SDM, they contribute less than half of the total IVI in the treatments. Nevertheless, it is notable that the highest values of Pinus were in the LC treatment (35.2\%), and this was because the pines had higher densities of small trees in this treatment following harvest of the largest trees. Furthermore, during removal, these harvested trees are dragged over other non-target species of the Others group in their path (N. Martínez-Meléndez, pers. obs.). In other words, the LC treatment was very effective in promoting the desired effect of the SDM.

The species in the Others group did not individually contribute more than $5 \%$ of IVI in any of the treatments, although together they accounted for more than $10 \%$ and the highest proportions were found in NT (15.24\%). In general, these non-oak broad leaf species are present in lower proportions in Quercus forests [20]. The species with the highest IVI was Ternstroemia tepezapote Schltdl. and Cham. (4.9\%), a mid-successional species that can establish rapidly once the pioneers leave [26].

Our results suggest that modifications through SDM achieve their objectives, bringing the forest close to an ideal silvicultural model that meets the requirements of production, regeneration, and conservation. The new structure and composition can fulfill certain parameters of diversity, conservation of ecosystem services and provision of habitat for different organisms, compared to the characteristics of the non-intervened forest.

\subsection{Implications for Management and Conservation}

Although the Ocotones forest has been under timber exploitation with a legal management plan for 14 years, we consider that documentation of the diversity and vegetation structure in the different silvicultural treatments in this period is important to understand the impact of the timber harvest on species conservation. Even though the treatments did not change tree species richness, other levels of diversity and structural values were affected.

The main objective of forest management in Mexico is not always the production of valuable timber. Even where timber production is declared the main management objective, it is generally accompanied by other objectives aimed at obtaining diverse nontimber products and services [6]. Our results support the affirmation that SDM favors the density of species of commercial interest, especially that of pines. The density of noncommercial species also decreased since managed sites have the objective of guaranteeing the regeneration of mainly Pinus species. Moreover, the current presence of Oaks group in the managed sites, safeguard the continuation of the process of forest succession and others ecological functions such as refugee of other species of flora that are threatened and are associated with Quercus, such as the epiphytes. For the rest of the species of the Others group, participation in forest recovery is not assured, given the constant elimination of non-commercial species.

Although the unmanaged areas currently conserve a higher density of Quercus than the managed areas, the Quercus species (which they have ecological and economic importance); Gil-Pelegrín et al. [52] recorded in this study are not included in any category of threat under the Official Mexican Norm for wildlife protection [53] or in the World Red List $[54,55]$ state that $Q$. peduncularis has been classified as one of the oak species most vulnerable to climate 
change and predict that it will undergo a loss of $25-45 \%$ of its distribution area. These reasons should be sufficient to define the unmanaged areas as priority sites for conservation of the Quercus species and to determine their role in the succession processes of these forests. In the same sense, these areas represent the habitat to support other successionally late broadleaf species, which reflects the intrinsic conservation value of these areas.

\section{Conclusions}

Our study shows that up to our sampling date, forest exploitation has not had a negative impact on effective species richness in the sampled sites ( 31 species in TH, 30 in NT, and 29 in LC). However, some important characteristics of the forest related to species composition and vegetation structure have been modified by the timber harvesting because of the intermediate objectives of applied forestry. Our data also indicate that tree density is recovering in managed areas: species of high timber value regenerate rapidly and recruitment of both pines and oaks is high. The SDM management, applied with local criteria, leads to the desired productive structure that maintains a species richness that is comparable to that of the non-intervened forest. Finally, we suggest further study of the impact of timber harvest on the diversity of other groups of organisms and under different conditions of land use.

Supplementary Materials: The following are available online at https:/ / www.mdpi.com/article/10.3 390/f12070895/s1. Table S1: Topographic attributes of each plot, in three silvicultural treatments in the Ocotones forest, southern Mexico; Table S2: Checklist of successional affinity and density of tree species evaluated under different forest management treatments in the Ocotones, southern Mexico: $\mathrm{TH}=$ Thinning, $\mathrm{LC}=$ Liberation cut, NT= No treatment. Successional affinity of species is $\mathrm{P}=$ pioneer, $\mathrm{M}=$ mid-successional, $\mathrm{L}=$ late (see [1-3]). The density of individuals represents all trees recorded in 120.1 circular plots located in each treatment; Table S3: Importance value index (IVI) (\%) of species group (Oaks, Pines and Others), in three silvicultural treatments in the Ocotones, southern Mexico. This index is estimated based on the sum of the relative density (RDe), relative dominance (RDo) (based on basal area), and relative frequency (RFr) of trees. IVI was calculated as: IVI= $(\mathrm{RDe}+\mathrm{RDo}+\mathrm{RFr}) / 3$.

Author Contributions: N.M.-M., N.R.-M., J.G.G.-F., P.M.-Z. and M.J.C.-P. designed the study; N.M.M., conducted the fieldwork; N.M.-M., N.R.-M. and J.G.G.-F. analyzed the results; N.M.-M. and N.R.-M. wrote the first version of the article; all authors contributed equally to the final manuscript. All authors have read and agreed to the published version of the manuscript.

Funding: This study was funded by the Mexican Council of Science and Technology (CONACYT, grant 341343/618822) for the doctoral scholarship awarded to the first author, the Rufford Foundation (Grant 25259-1) and from federal funds allotted to ECOSUR.

Acknowledgments: A. Gómez and V. Gómez for their permission to conduct botanical collection in the Ocotones forest. We thank S. Valencia for taxonomic determination of Quercus specimens, J.R. Ramos Moreno, J. Jiménez Guillén and J. Gómez Girón for guiding the field visits and M.F. Cruz Jiménez, V.D. Castillo Amaya, J.W. López Santiago, A. López Cruz, V. García Mendoza, L.E. Sánchez Cuesta, S. M. Isidro, E. Gómez Pérez, E.A. Montoya Cabrera, A. Osorio González, E. Reyes Grajales and L.F. González Martínez aided during fieldwork. D.A. Jiménez-López produced the location map. We thank Keyth MacMillan for translation and reviewing style.

Conflicts of Interest: The authors declared no potential conflicts of interest with respect to the research, authorship, and/or publication of this article.

\section{References}

1. Kotru, R.; Sharma, S. Review forest users: Past, present, future. In Silviculture in the Tropics; Günter, S., Weber, M., Stimm, B., Eds.; Springer: Berlin/Heidelberg, Germany, 2011; pp. 13-33, ISBN 978-3-642-19985-1.

2. FAO; UNEP. The State of the World's Forests 2020. Forest, Biodiversity and People; Food and Agriculture Organization of the United Nations: Rome, Italy, 2020; ISBN 978-92-5-132419-6.

3. Farrell, E.P.; Führer, E.; Ryan, D.; Andersson, F.; Hüttl, R.; Piussi, P. European forest ecosystems: Building the future on the legacy of the past. For. Ecol. Manag. 2000, 132, 5-20. [CrossRef]

4. Asner, G.P.; Rudel, T.K.; Aide, T.M.; Defries, R.; Emerson, R. A contemporary assessment of change in humid tropical forests. Conserv. Biol. 2009, 23, 1386-1395. [CrossRef] [PubMed] 
5. Sist, P.; Rutishauser, E.; Peña-Claros, M.; Shenkin, A.; Hérault, B.; Blanc, L.; Baraloto, C.; Baya, F.; Benedet, F.; da Silva, K.E.; et al. The tropical managed forests observatory: A research network addressing the future of tropical logged forests. Appl. Veg. Sci. 2015, 18, 171-174. [CrossRef]

6. Torres-Rojo, J.M.; Moreno-Sánchez, R.; Mendoza-Briseño, M.A. Sustainable forest management in Mexico. Curr. For. Rep. 2016, 2, 93-105. [CrossRef]

7. Rosales, S.P.H.; Olayo, G.M.A.; Morales, F.J.A.; Alvares, R.R.; Martínez, H.I. El Método de Desarrollo Silvícola, una alternativa en la silvicultura y ordenación de bosques. Rev. Chapingo Ser. Ciencias For. Ambient. 1982, 7, 69-72.

8. Bray, D.B.; Merino-Pérez, L. The Rise of Community Forestry in Mexico: History, Concepts, and Lessons Learned from Twenty-Five Years of Community timber Production. A Report in Partial Fulfillment of Grant No. 1010-0595; The Ford Fundation: Mexico City, Mexico, 2002.

9. Moreno-Sánchez, R.; Torres-Rojo, J.M. Decision support systems for forest management in Mexico: Their characteristics and context for their creation and evolution. In Decision Support Systems in Agriculture, Food and the Environment: Trends, Applications and Advances; Manos, B., Paparrizos, J., Papathanasiou, K., Eds.; IGI Global: Hershey, PA, USA, 2010; pp. 74-100, ISBN 9781615208814.

10. Pérez-López, R.I.; González-Espinosa, M.; Ramírez-Marcial, N.; Toledo-Aceves, T. Efectos del "Método de Desarrollo Silvícola" sobre la diversidad arbórea en bosques húmedos de montaña del norte de Chiapas, México. Rev. Mex. Biodivers. $2020,91$. [CrossRef]

11. Jiménez, L.B.; Damon, A.; Ochoa-Gaona, S.; Tapia, R.C. Impact of silvicultural methods on vascular epiphytes (ferns, bromeliads and orchids) in a temperate forest in Oaxaca, Mexico. For. Ecol. Manag. 2014, 329, 10-20. [CrossRef]

12. Ruíz-Pérez, I.; León-Cortés, J.L.; Arellano, L.; Navarrete, D.A. Manejo forestal comunitario en el sur de México: ¿es una práctica sustentable para el mantenimiento de los ensambles de escarabajos? Rev. Mex. Biodivers. 2019, 90, e902564. [CrossRef]

13. Villaseñor, J.L. El Bosque Húmedo de Montaña en México y sus Plantas Vasculares: Catálogo Florístico-Taxonómico; Comisión Nacional para el Conocimiento y Uso de la Biodiversidad: Mexico City, Mexico, 2010; ISBN 978-607-02-1557-5.

14. Ding, Y.; Zang, R.; Lu, X.; Huang, J. The impacts of selective logging and clear-cutting on woody plant diversity after 40 years of natural recovery in a tropical montane rain forest, south China. Sci. Total Environ. 2017, 579, 1683-1691. [CrossRef] [PubMed]

15. Giam, X. Global biodiversity loss from tropical deforestation. Proc. Natl. Acad. Sci. USA 2017, 114, 5775-5777. [CrossRef]

16. Santini, N.S.; Adame, M.F.; Nolan, R.H.; Miquelajauregui, Y.; Piñero, D.; Mastretta-Yanes, A.; Cuervo-Robayo, Á.P.; Eamus, D. Storage of organic carbon in the soils of Mexican temperate forests. For. Ecol. Manag. 2019, 446, 115-125. [CrossRef]

17. Jardel, P.E. El manejo forestal en México: Estado actual y perspectivas. In Estado de los Bosques de México; Chapela, F., Ed.; Consejo Civil Mexicano para la Silvicultura Sostenible A.C.: Mexico City, Mexico, 2012; pp. 69-115.

18. PMLO. Programa de Manejo Forestal del Predio Particular Los Ocotones, Municipio de Cintalapa, Chiapas. Plan Maestro Los Ocotones S.P.R. de C.V. de R.L.; 2013; Unpublished Report. Available online: http:/ / sinat.semarnat.gob.mx/dgiraDocs/documentos/CUSF/ 07L702120214.pdf (accessed on 9 June 2021).

19. Arriaga, L.C.; Espinoza, J.M.; Aguilar, C.Z.; Martínez, E.R.; Gómez, L.M.; Loa, E.L. Regiones Terrestres Prioritarias de México; Comisión Nacional para el Conocimiento y Uso de la Biodiversidad: Ciudad de Mexico, Mexico, 2000; ISBN 970-9000-16-0.

20. Breedlove, D.E. Flora of Chiapas. Part I: Introduction to The Flora of Chiapas; California Academy of Sciences: San Francisco, CA, USA, 1981; ISBN 0940228009.

21. Gerez, P.; Purata, S.E. Guía Práctica Forestal de Silvicultura Comunitaria; SEMARNAT/CONAFOR/CCMSS: Mexico City, Mexico, 2008; ISBN 9781424323135.

22. QGIS Development Team Quantum GIS Geographic Information System. Open Source Geospatial Foundation Project 2016. Available online: https:/ / qgis.org/en/site/ (accessed on 9 January 2018).

23. Del Carpio, C.U.P. Recursos forestales y dinámica territorial en la frontera Chimalapa. In Presencia Zoque. Una Aproximación Multidisciplinaria; Universidad de Ciencias y Artes de Chiapas: Tuxtla Gutiérrez, Chiapas, México, 2006; pp. 47-74. ISBN 9685149453.

24. Newton, A.C. Forest Ecology and Conservation. A Handbook of Techniques; Oxford University Press: Oxford, UK, 2007; ISBN 9780198567455.

25. González-Espinosa, M.; Ramírez-Marcial, N.; Galindo-Jaimes, L. Secondary succession in montane pine-oak forests of Chiapas, Mexico. In Ecology and Conservation of Neotropical Montane Oak Forests; Kapelle, M., Ed.; Springer: Berlin/Heidelberg, Germany, 2006; Volume 185, pp. 209-221, ISBN 978-3-540-28909-8.

26. Rocha-Loredo, A.G.; Ramírez-Marcial, N.; González-Espinosa, M. Riqueza y diversidad de árboles del bosque tropical caducifolio en la Depresión Central de Chiapas. Bol. Soc. Bot. México 2010, 87, 89-103. [CrossRef]

27. Martínez-Camilo, R.; González-Espinosa, M.; Ramírez-Marcial, N.; Cayuela, L.; Pérez-Farrera, M.Á. Tropical tree species diversity in a mountain system in southern Mexico: Local and regional patterns and determinant factors. Biotropica 2018, 50, 499-509. [CrossRef]

28. Roscher, C.; Gerighausen, U.; Schmid, B.; Schulze, E.D. Plant diversity and community history shift colonization success from early- to mid-successional species. J. Plant Ecol. 2014, 8, 231-241. [CrossRef]

29. Ramírez-Marcial, N.; Camacho-Cruz, A.; González-Espinosa, M.; Golicher, D. Clasificación de grupos funcionales vegetales para la restauración del bosque mesófilo de montaña. In Ecología, Manejo y Conservación de los Ecosistemas de Montaña en México; Sánchez-Velásquez, L.R., Galindo-González, J., Díaz-Fleischer, F., Eds.; Mundi Prensa Mexico: Mexico City, Mexico, 2008; pp. 51-72, ISBN 9789687462578.

30. Crawley, M.J. The R Book; John Wiley \& Sons: West Sussex, UK, 2013; ISBN 978-0-470-97392-9. 
31. Ripley, B.; Venables, B.; Bates, D.M.; Hornik, K.; Gebhardt, A.; Firth, D. Package MASS. Cran-R Project 2019. Available online: http://www.stats.ox.ac.uk/pub/MASS4/ (accessed on 6 December 2019).

32. Hothorn, T.; Bretz, F.; Westfall, P.; Heiberger, R.; Schuetzenmeister, A.; Scheibe, S. Package multcomp. R Documentation. Available online: http:/ / multcomp.R-forge.R-project.org (accessed on 6 December 2019).

33. R Core Team R: A Language and Environmental for Statistical Computing; R Foundation for Statistical Computing. Available online: https: / /www.r-project.org/ (accessed on 14 January 2019).

34. Jost, L. Entropy and diversity. Oikos 2006, 113, 363-375. [CrossRef]

35. Hsieh, T.C.; Ma, K.H.; Chao, A. iNEXT: An R package for rarefaction and extrapolation of species diversity (Hill numbers). Methods Ecol. Evol. 2016, 7, 1451-1456. [CrossRef]

36. Ramírez-Marcial, N.; Camacho-Cruz, A.; González-Espinosa, M.; López-Barrera, F. Establishment, survival and growth of tree seedlings under successional montane oak forests in Chiapas, Mexico. In Ecology and Conservation of Neotropical Montane Oak Forests; Kapelle, M., Ed.; Springer: Berlin/Heidelberg, Germany, 2006; Volume 185, pp. 177-189, ISBN 978-3-540-28909-8.

37. Garcia-Florez, L.; Vanclay, J.K.; Glencross, K.; Nichols, J.D. Understanding 48 years of changes in tree diversity, dynamics and species responses since logging disturbance in a subtropical rainforest. For. Ecol. Manag. 2017, 393, 29-39. [CrossRef]

38. Hu, J.; Herbohn, J.; Chazdon, R.L.; Baynes, J.; Wills, J.; Meadows, J.; Sohel, M.S.I. Recovery of species composition over 46 years in a logged Australian tropical forest following different intensity silvicultural treatments. For. Ecol. Manag. 2018, 409, 660-666. [CrossRef]

39. Cayuela, L.; Golicher, D.J.; Benayas, J.M.R.; González-Espinosa, M.; Ramírez-Marcial, N. Fragmentation, disturbance and tree diversity conservation in tropical montane forests. J. Appl. Ecol. 2006, 43, 1172-1181. [CrossRef]

40. Wang, H.; Feng, H.; Zhang, Y.; Chen, H. Contrasting regeneration strategies in climax and long-lived pioneer tree species in a subtropical forest. PLoS ONE 2014, 9. [CrossRef]

41. González-Espinosa, M.; Ramírez-Marcial, N.; Mendez-Dewar, G.; Galindo-Jaimes, L.; Golicher, D.J. Riqueza de especies de árboles en Chiapas: Variación espacial y dimensiones ambientales asociadas al nivel regional. In Diversidad Biológica de Chiapas; González-Espinosa, M., Ramírez-Marcial, N., Ruíz-Montoya, L., Eds.; ECOSUR, COCYTECH, Plaza y Valdés: Mexico City, Mexico, 2005; pp. 81-125, ISBN 970-722-399-5.

42. Zahawi, R.A.; Holl, K.D.; Cole, R.J.; Reid, J.L. Testing applied nucleation as a strategy to facilitate tropical forest recovery. J. Appl. Ecol. 2013, 50, 88-96. [CrossRef]

43. Torras, O.; Gil-Tena, A.; Saura, S. Changes in biodiversity indicators in managed and unmanaged forests in NE Spain. J. For. Res. 2012, 17, 19-29. [CrossRef]

44. Faison, E.K.; DeStefano, S.; Foster, D.R.; Rapp, J.M.; Compton, J.A. Multiple browsers structure tree recruitment in logged temperate forests. PLoS ONE 2016, 11. [CrossRef]

45. Putz, F.E.; Blate, G.M.; Redford, K.H.; Fimbel, R.; Robinson, J. Tropical forest management and conservation of biodiversity: An overview. Conserv. Biol. 2001, 15, 7-20. [CrossRef]

46. Shima, K.; Yamada, T.; Okuda, T.; Fletcher, C.; Kassim, A.R. Dynamics of tree species diversity in unlogged and selectively logged Malaysian forests. Sci. Rep. 2018, 8, 1-8. [CrossRef]

47. Galindo-Jaimes, L.; González-Espinosa, M.; Quintana-Ascencio, P.; García-Barrios, L. Tree composition and structure in disturbed stands with varying dominance by Pinus spp. in the highlands of Chiapas, México. Plant Ecol. 2002, 162, 259-272. [CrossRef]

48. González-Tagle, M.A.; Schwendenmann, L.; Pérez, J.J.; Schulz, R. Forest structure and woody plant species composition along a fire chronosequence in mixed pine-oak forest in the Sierra Madre Oriental, northeast Mexico. For. Ecol. Manag. 2008, 256, 161-167. [CrossRef]

49. Rutten, G.; Ensslin, A.; Hemp, A.; Fischer, M. Forest structure and composition of previously selectively logged and non-logged montane forests at Mt. Kilimanjaro. For. Ecol. Manag. 2015, 337, 61-66. [CrossRef]

50. Alfaro, T.R.; Martínez-Vilalta, J.; Retana, J. Regeneration patterns in Mexican pine-oak forests. For. Ecosyst. 2019, 6, 1-12. [CrossRef]

51. Trujillo-Miranda, A.L.; Toledo-Aceves, T.; López-Barrera, F.; Günter, S. Tree diversity and timber productivity in planted forests: Pinus patula versus mixed cloud forest species. New For. 2021, 52, 177-195. [CrossRef]

52. Gil-Pelegrín, E.; Peguero-Pina, J.J.; Sancho-Knapik, D. Oaks and People: A Long Journey Together. In Oaks Physiological Ecology. Exploring the Functional Diversity of Genus Quercus L.; Gil-Pelegrín, E., Peguero-Pina, J.J., Sancho-Knapik, D., Eds.; Springer: Gewerbestrasse, Switzerland, 2017; Volume 7, pp. 1-11, ISBN 978-3-319-69098-8.

53. SEMARNAT. Norma Oficial Mexicana NOM-059-SEMARNAT; Protección Ambiental-Especies Nativas de México de Flora y Fauna Silvestres, Categorías de Riesgo y Especificaciones Para su Inclusión, Exclusión o Cambio, Lista de Especies en Riesgo. Available online: https://dof.gob.mx/nota_detalle_popup.php?codigo=5173091 (accessed on 10 March 2020).

54. IUCN. The IUCN Red List of Threatened Species. Version 2020-3. Available online: https:/ / www.iucnredlist.org/es/ (accessed on 8 January 2020).

55. Gómez-Mendoza, L.; Arriaga, L. Modeling the effect of climate change on the distribution of oak and pine species of Mexico. Conserv. Biol. 2007, 21, 1545-1555. [CrossRef] [PubMed] 